\title{
On the impact of Gold Open Access Journals
}

\author{
Christian Gumpenberger ${ }^{1,}$ María-Antonia Ovalle-Perandones ${ }^{2}$ \& Juan Gorraiz ${ }^{1}$ \\ ${ }^{1}$ University of Vienna $\mid{ }^{2}$ Carlos III University of Madrid
}

\begin{abstract}
Gold Open Access (= Open Access publishing) is for many the preferred route to achieve unrestricted and immediate access to research output. However, true Gold Open Access journals are still outnumbered by traditional journals. Moreover availability of Gold OA journals differs from discipline to discipline and often leaves scientists concerned about the impact of these existent titles. This study identified the current set of Gold Open Access journals featuring a Journal Impact Factor (JIF) by means of Ulrichsweb, Directory of Open Access Journals (DOAJ) and Journal Citation Reports (JCR). The results were analyzed regarding disciplines, countries, quartiles of the JIF distribution in JCR and publishers. Furthermore the temporal impact evolution was studied for a Top 50 titles list (according to Journal Impact Factor) by means of Journal Impact Factor, SJR and SNIP in the time interval 2000-2010. The identified Top Gold Open Access journals proved to be well-established and their impact is generally increasing for all the analyzed indicators. The majority of JCRindexed OA journals can be assigned to Life Sciences and Medicine. The success-rate for JCR inclusion differs from country to country and is often inversely proportional to the number of national OA journal titles. Compiling a list of JCR-indexed OA journals is a cumbersome task that can only be achieved with non-Thomson Reuters data sources. A corresponding automated feature to produce current lists "on the fly" would be desirable in JCR in order to conveniently track the impact evolution of Gold OA journals.
\end{abstract}

\section{Keywords}

Gold Open Access, Open Access Publishing, Journal Impact Factor, SNIP, SJR, impact analysis, impact evolution, Ulrichsweb, Directory of Open Access Journals (DOAJ), Journal Citation Reports (JCR)

\section{Background}

Open Access delivered by journals (regardless of the business model) is generally referred to as Gold Open Access (Suber, 2004; Schmidt, 2007; Oppenheim, 2008). Currently there are $>8000$ Open Access Journals listed in the Directory of Open Access Journals (DOAJ) ${ }^{1}$, out of

\footnotetext{
${ }^{1}$ Available: http://www.doaj.org [Accessed: August 08, 2012].
} 
a total of $>26000$ estimated peer-reviewed scholarly journals worldwide ${ }^{2}$. There has been much debate whether OA articles have a higher impact in contrast to non-OA ones (Craig et al. 2007; Harnad et al.; 2008, Swan, 2010; Wagner, 2010). A most recent study by Björk and Solomon (2012) compared the scientific impact of Open Access publications on the journal as well as on the article level.

Moreover the different ways to achieve OA are heavily discussed. Some favour Green OA (Harnad et al., 2008), others perceive Green and Gold OA to be embraced in coexistence (Guédon, 2008), whereas the rest assume Gold OA as the preferred route, since in their rationale Green OA often comes with embargos and cannot work alongside the subscriptionbased publication model without restrictions (Jubb et al., 2011).

Only few studies have so far tracked the evolution of OA journals regarding their inclusion in JCR and their impact (McVeigh, 2004; Testa and McVeigh, 2004; Sotudeh and Horri, 2007; Giglia, 2010).

Like it or not, it is a fact that academic careers are still primarily determined by impact indicators, even if they are often misused. Therefore it cannot be stressed often enough that being indexed in the Web of Science (WoS) and the Journal Citation Reports (JCR) rather reflects a journal's prestige or influence (= impact) within the scientific community than its quality. WoS and JCR only select the most prestigious journals ${ }^{3}$, and according to the 80-20 rule (Pareto principle) ${ }^{4}$, Bradford's Law ${ }^{5}$ and Garfield's Law (Garfield, 1971) a relatively small number of journals publish the most relevant and most cited research in any fields.

Apart from the Journal Impact Factor (JIF) new journal impact measures like SJR and SNIP should also be taken into consideration to judge a journal's impact.

Scientists are concerned that OA journals with sufficiently high impact might be either nonexistent or very hard to find. It is critical for them to increase their own visibility by publishing in a prestigious journal. Impact is of utmost concern, and it is therefore legitimate to continuously shed light on the impact evolution of Gold Open Access journals.

\footnotetext{
${ }^{2}$ Appendix C: how many active, scholarly peer reviewed journals? Available: http://pages.cmns.sfu.ca/heather-morrison/appendix-c-how-many-active-scholarly-peer-reviewedjournals/ [Accessed: April 10, 2012].

${ }^{3}$ The Thomson Reuters journal selection process. Available: http://thomsonreuters.com/products services/science/free/essays/journal_selection_process/ [Accessed: October 29, 2012]

${ }^{4}$ Pareto principle. Available: http://en.wikipedia.org/wiki/Pareto_principle [Accessed: October 29, 2012]

${ }^{5}$ Bradford's Law. Available: http://en.wikipedia.org/wiki/Bradford\%27s_law [Accessed: October 29, 2012]
} 


\section{Aims}

The aims of this study are:

1) to identify the number of Gold Open Access Journals that have successfully taken the hurdle to be indexed in JCR and allocated to disciplines, countries and quartiles

2) to analyze the temporal evolution of the Gold Open Access journals' impact and prestige by means of different journal impact measures (Journal Impact Factor, SNIP and SJR)

The results will hopefully inform further decisions taken regarding supportive Gold Open Access Policy initiatives.

\section{Methodology}

Data analysis relied on multiple information resources: Ulrichsweb ${ }^{\mathrm{TM}}$ as a global serials directory, the Journal Citation Reports (Thomson Reuters, 2010 edition), the Directory of Open Access Journals (DOAJ), the Scimago Journal \& Country Rank (SJCR) by Scimago Research Group, and the CWTS Journals Indicators website by Center for Science and Technology Studies, Leiden University.

Open Access journals were initially retrieved from Ulrichsweb, since it provides Open Access as well as JCR relevant information. For this purpose "Open Access" as well as "Journal Citation Reports" was chosen in the database's "Key features" with further restrictions to "Journal" as "Serial Types" and "Online" and "Print" (the latter is necessary in order to avoid exclusion of relevant titles) as "Format". The retrieved OA records were deduplicated manually and cross-checked with DOAJ and JCR. The final set of journal titles was then analyzed regarding publisher countries and subject fields. For the latter the 22 ESI (Essential Science Indicators) Categories were used representing the aggregated WoS Subject Categories. These were then compared to the most corresponding subject categories available in DOAJ.

Furthermore, the Quartiles ${ }^{6}$ for all the retrieved journals were compiled from the 2010 editions of JCR. Multiple assignments were counted "normally", i.e. separate counting for each quartile range.

Finally, ranked by maximum Impact Factor a list of top 50 titles was compiled for further analysis regarding the temporal evolution of the Impact Factor, SNIP and SJR in the time period 2001-2010.

\footnotetext{
${ }^{6}$ It is important to know that JCR refers to Q1 as the highest quartile including the category's top 25\% journals, whereas Q1 in conventional descriptive statistics delimits the lower $25 \%$ of the distribution
} 
Journal Impact measures were obtained respectively from:

1. Thomson Scientific Journal Citation Reports (JCR), Science and Social Science editions for the years 2000-2010.

2. SCImago Journal Rank (SJR) indicator (SCImago, 2007), developed by Vicente Guerrero and Félix de Moya and inspired by Google PageRank ${ }^{\mathrm{TM}}$. SCImago is a research group from the "Consejo Superior de Investigaciones Científicas" (CSIC), University of Granada, Extremadura, Carlos III (Madrid) and Alcalá de Henares. SJR was designed for ranking scholarly journals based on citation weighting schemes and eigenvector centrality (González-Pereira et al., 2010).

3. "CWTS - Journal Indicators". This website, maintained by the Centre for Science and Technology Studies (CWTS) of the Leiden University, is dedicated to the development, dissemination and discussion of journal indicators. Their indicator Source-Normalized Impact per Paper (SNIP), was introduced 2010 by Henk Moed (Moed, 2010a, 2010b) and addresses differences in citation behaviour between research fields. It is based on Garfield's citation potential (1979) and the idea of source normalization, termed by Zitt and Small (2008) as "citing-side normalization". A journal's Source Normalized Impact per Paper (SNIP) = Raw Impact per Paper published in the journal (RIP) $\div$ Relative Database Citation Potential (RDCP) in the journal's subfield (Moed, 2010b).

The timelines of all three indicators (IF, SJR and SNIP) were analyzed for the time range $2001-2010$.

Trend lines corresponding to the linear regression $(\mathrm{X}=\mathrm{aY}+\mathrm{b}$; and the corresponding coefficient of determination R-squared (which determines how closely a graph's trend line corresponds to the actual data points on the graph) were calculated in Excel. Trend lines are an important tool in technical analysis for both trend identification and confirmation. An uptrend line has a positive slope and a downtrend line has a negative slope. According to this fact all timelines were classified in 3 groups:

$\leftrightarrow=$ rather flat trend line: either insignificant increase or decrease

$\uparrow=$ increase: positive slope

$\downarrow=$ decrease: negative slope

n.a. $=$ not applicable (missing or insufficient values)

In order to allow easy interpretation in the results part, examples for each trend line type are given below in Figures 1-3 regarding the IF evolution. 


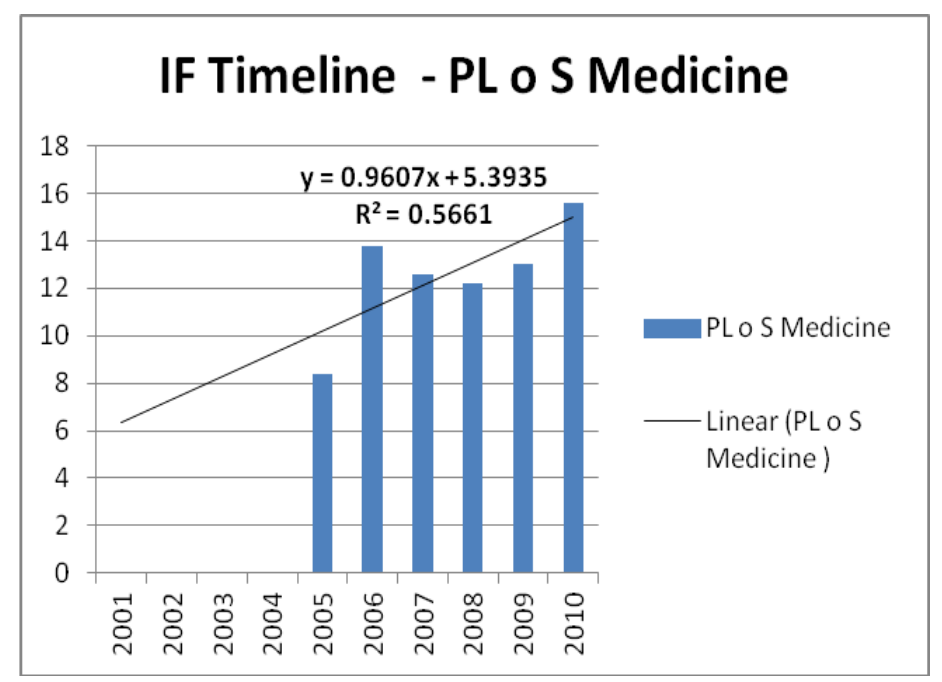

Figure 1: Example of $\uparrow=$ increase

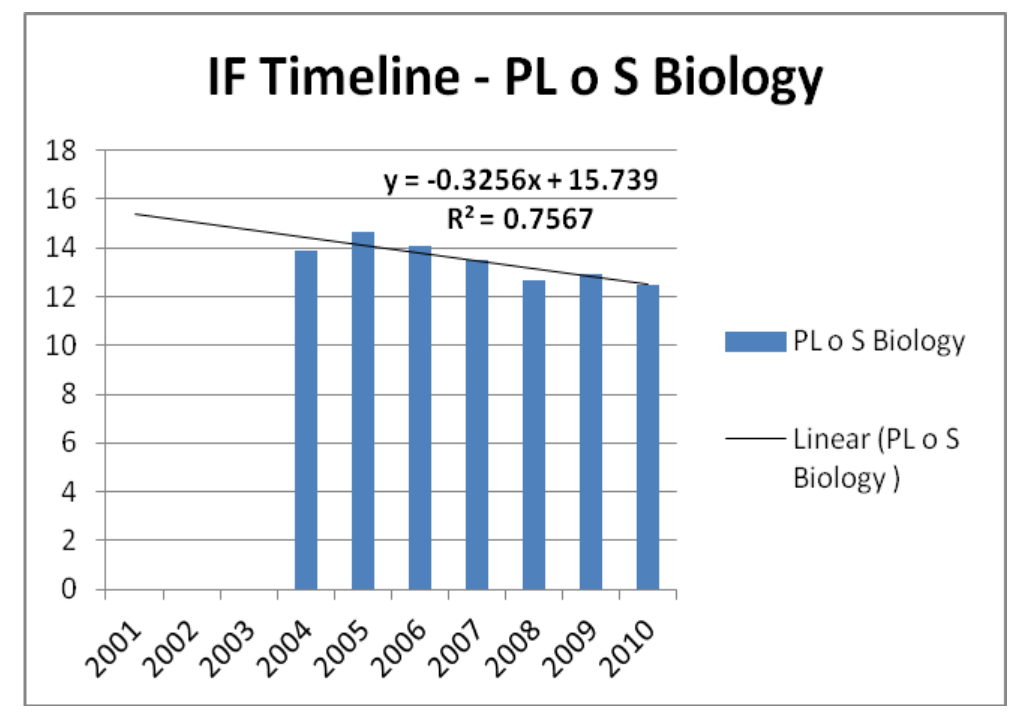

Figure 2: Example of $\downarrow=$ decrease 


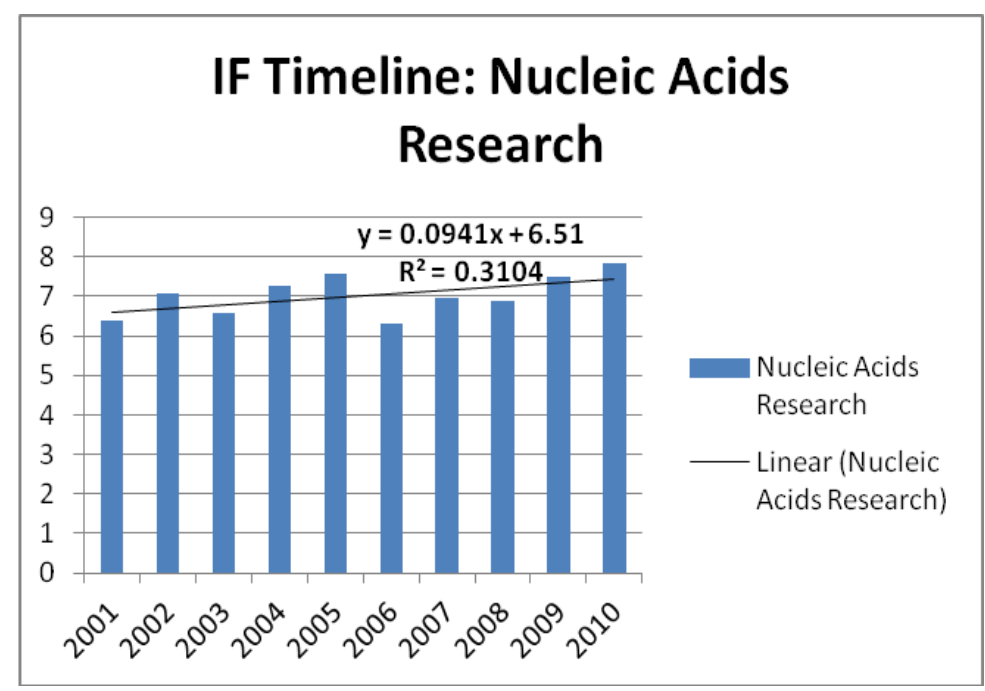

Figure 3: Example of $\leftrightarrow=$ flat trend line

On the occasion of gaps or discrepancies observed in the indicator timelines (positive as well as negative slopes) (e.g. PLoS Biology, Figure $8 \rightarrow$ see Results), further background information was considered from each data source in order to find plausible explanations.

Finally, Spearman correlation analysis was performed for the Top 50 titles for all 3 journal impact measure values compiled for all 10 years in this study.

\section{Results}

\section{1) OA Journals in Ulrichsweb and DOAJ, Comparison with JCR}

Table 1 lists the Top 10 countries regarding the number of OA journal titles according to Ulrich. The corresponding count for DOAJ and the total number of journal titles in JCR are given as well. Austria and Switzerland are included as German speaking countries for comparison reasons with Germany. The country distribution is depicted in Figure 4.

Table 1: Top 10 countries regarding OA journals (according to Ulrichsweb)

\begin{tabular}{|c|c|c|c|c|}
\hline Rank & Country & $\begin{array}{l}\text { \# OA journal } \\
\text { titles in Ulrich } \\
\text { (deduplicated) }\end{array}$ & \begin{tabular}{|l}
$\#$ \\
journal \\
titles in \\
DOAJ \\
2012
\end{tabular} & $\begin{array}{l}\text { \# journal } \\
\text { titles in } \\
\text { JCR } \\
2010 \text { - } \\
\text { total }\end{array}$ \\
\hline 1 & United States & 1270 & 1231 & 3718 \\
\hline 2 & Brazil & 659 & 753 & 103 \\
\hline 3 & United Kingdom & 521 & 546 & 2176 \\
\hline
\end{tabular}




\begin{tabular}{|l|l|r|r|r|}
\hline 4 & Spain & 401 & 417 & 120 \\
\hline 5 & India & 398 & 425 & 99 \\
\hline 6 & Netherlands & 273 & 63 & 787 \\
\hline 7 & Germany & 238 & 249 & 638 \\
\hline 8 & Canada & 233 & 239 & 114 \\
\hline 9 & Romania & 222 & 229 & 53 \\
\hline 10 & Italy & 203 & 215 & 128 \\
\hline$*$ & Switzerland & 107 & 106 & 184 \\
\hline$*$ & Austria & 37 & 40 & 41 \\
\hline
\end{tabular}

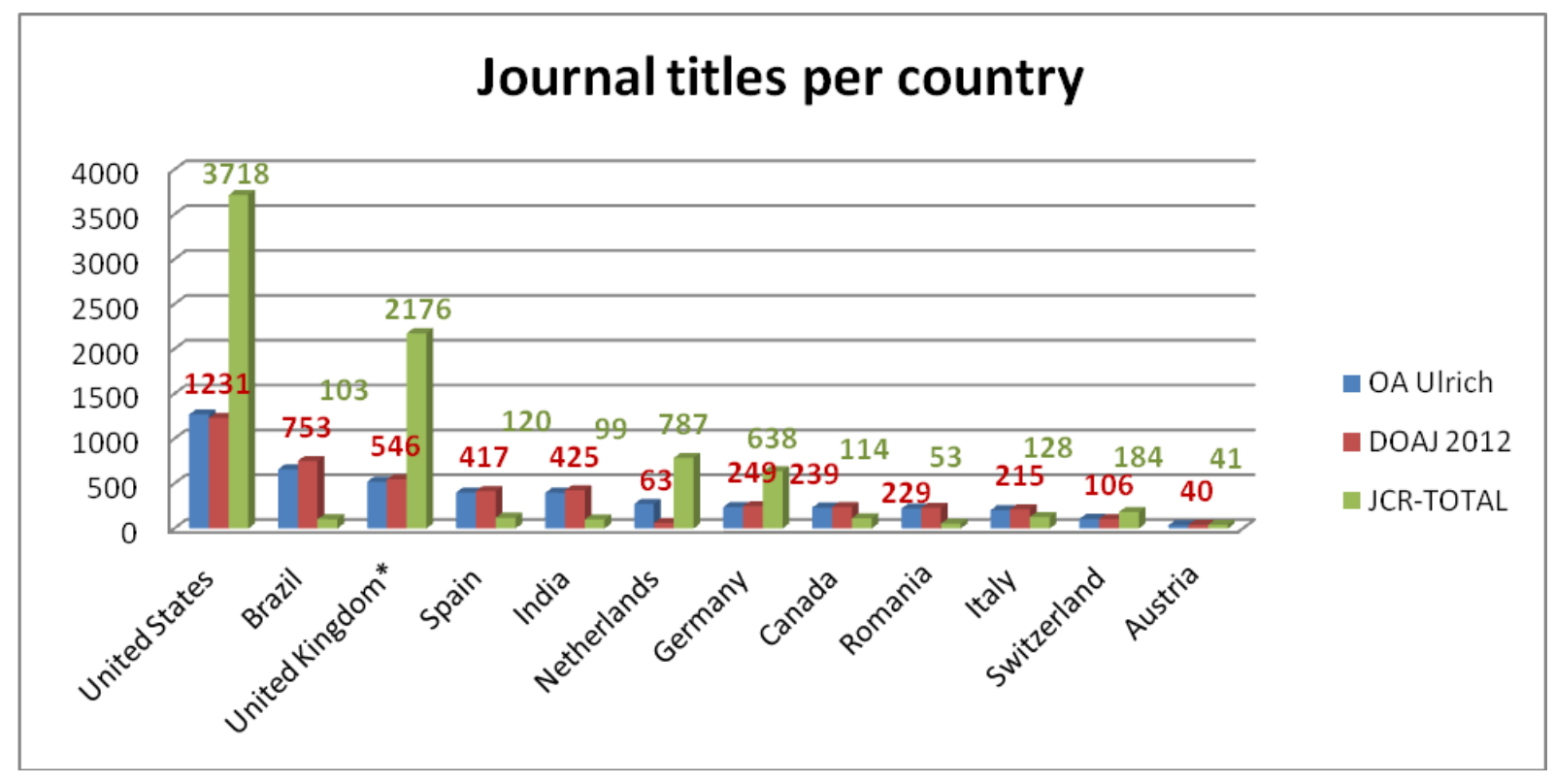

Figure 4: Country distribution of journal titles

\section{2) Identification of OA Journals in JCR}

990 OA journal titles were initially retrieved in Ulrichsweb (format "Print" or "Online") and finally narrowed down to 862 OA titles indexed in JCR (757 titles in the Science Edition SCI and 128 in the Social Science Edition SSCI, with an overlap of 23 titles). The final list was obtained after manual deduplication and cross-check with DOAJ.

According to Ulrichsweb 862 OA titles were retrieved, according to DOAJ the number was slightly higher with 884 retrieved OA titles. 32 titles appear in Ulrichsweb but not in DOAJ, whereas 54 titles are indexed in DOAJ but not in Ulrichsweb. The majority of 830 OA titles were available in both databases.

Table 2 shows the Top 20 countries regarding OA journals that are indexed in JCR. The bolded countries are the ones with more than $20 \%$ successfully JCR-indexed titles compared to the overall count in DOAJ. The German speaking countries are presented in italics. 
Table 2: Top 20 countries regarding indexed OA journals in JCR (according to Ulrich and DOAJ)

\begin{tabular}{|r|l|r|r|r|r|r|}
\hline & $\begin{array}{c}\text { \# OA } \\
\text { Titles in } \\
\text { JCR acc. } \\
\text { Ulrich }\end{array}$ & $\begin{array}{c}\text { \# OA } \\
\text { Titles in } \\
\text { JCR acc. } \\
\text { DOAJ }\end{array}$ & $\begin{array}{c}\text { \# } \\
\text { overall } \\
\text { titles in } \\
\text { DOAJ }\end{array}$ & $\begin{array}{c}\text { \% in } \\
\text { JCR } \\
\text { acc. } \\
\text { DOAJ }\end{array}$ & $\begin{array}{c}\text { \% in } \\
\text { JCR } \\
\text { acc. } \\
\text { Ulrich }\end{array}$ \\
\hline 1 & United Kingdom & 110 & 113 & 546 & 20.70 & 20.15 \\
\hline 2 & United States & 105 & 110 & 1231 & 8.94 & 8.53 \\
\hline 3 & Brazil & 83 & 90 & 753 & 11.95 & 11.02 \\
\hline 4 & Japan & 45 & 44 & 106 & 41.51 & 42.45 \\
\hline 5 & India & 42 & 43 & 425 & 10.12 & 9.88 \\
\hline 6 & Spain & 39 & 42 & 417 & 10.07 & 9.35 \\
\hline 7 & Germany & 39 & 39 & 249 & 16.06 & 16.06 \\
\hline 8 & Poland & 36 & 36 & 135 & 26.67 & 26.67 \\
\hline 9 & Turkey & 29 & 30 & 199 & 15.08 & 14.57 \\
\hline 10 & Chile & 28 & 30 & 140 & 21.43 & 20 \\
\hline 11 & Mexico & 28 & 29 & 122 & 23.77 & 22.95 \\
\hline 12 & Croatia & 19 & 19 & 87 & 21.84 & 21.84 \\
\hline 13 & Colombia & 18 & 20 & 187 & 10.70 & 9.63 \\
\hline 14 & Iran & 18 & 18 & 145 & 12.41 & 12.41 \\
\hline 15 & Serbia & 16 & 16 & 79 & 20.25 & 20.25 \\
\hline 16 & Czech Republic & 14 & 14 & 61 & 22.95 & 22.95 \\
\hline 17 & Switzerland & 13 & 13 & 106 & 12.26 & 12.26 \\
\hline 18 & Italy & 12 & 13 & 215 & 6.05 & 5.58 \\
\hline 19 & South Korea & 11 & 11 & 39 & 28.21 & 28.21 \\
\hline 20 & South Africa & 11 & 11 & 47 & 23.40 & 23.4 \\
\hline 21 & Canada & 10 & 10 & 239 & 4.18 & 4.18 \\
\hline 54 & Austria & 2 & 2 & 40 & 5.00 & 5 \\
\hline & & & & & \\
\hline
\end{tabular}

\section{3) OA Journals in JCR - allocation of titles to disciplines, countries and quartiles}

Table 3 shows the allocation of OA titles to ESI and corresponding DOAJ subject categories. The last column gives the percentage of JCR-indexed OA titles per subject category.

Table 3: OA journals in JCR assigned to ESI categories

\begin{tabular}{|l|l|r|r|l|}
\hline Rank & ESI - Subject Categories & $\begin{array}{c}\text { \# OA } \\
\text { titles } \\
\text { in } \\
\text { JCR }\end{array}$ & $\begin{array}{c}\text { \# titles in } \\
\text { corresponding } \\
\text { DOAJ } \\
\text { category }\end{array}$ & $\begin{array}{c}\text { \% in } \\
\text { JCR }\end{array}$ \\
\hline 1 & Clinical Medicine & 250 & 492 & $50.81 \%$ \\
\hline 2 & Plant \& Animal Science & 105 & 162 & $64.81 \%$ \\
\hline
\end{tabular}




\begin{tabular}{|l|l|r|r|r|}
\hline 3 & Social Sciences, general & 102 & 302 & $33.77 \%$ \\
\hline 4 & Biology \& Biochemistry & 71 & 358 & $19.83 \%$ \\
\hline 5 & Engineering & 60 & 495 & $12.12 \%$ \\
\hline 6 & Geosciences & 54 & 117 & $46.15 \%$ \\
\hline 7 & Chemistry & 46 & 159 & $28.93 \%$ \\
\hline 8 & Mathematics & 43 & 212 & $20.28 \%$ \\
\hline 9 & Agricultural Sciences & 40 & 151 & $26.49 \%$ \\
\hline 10 & Molecular Biology \& Genetics & 35 & 55 & $63.64 \%$ \\
\hline 11 & Pharmacology \& Toxicology & 31 & 98 & $31.63 \%$ \\
\hline 12 & Materials Science & 29 & 39 & $74.36 \%$ \\
\hline 13 & Physics & 27 & 83 & $32.53 \%$ \\
\hline 14 & Neuroscience \& Behavior & 24 & 125 & $19.20 \%$ \\
\hline 15 & Environment/Ecology & 21 & 183 & $11.48 \%$ \\
\hline 16 & Economics \& Business & 20 & 450 & $4.44 \%$ \\
\hline 17 & Computer Science & 18 & 332 & $5.42 \%$ \\
\hline 18 & Microbiology & 18 & 59 & $30.51 \%$ \\
\hline 19 & Psychiatry/Psychology & 18 & 234 & $7.69 \%$ \\
\hline 20 & Multidisciplinary & 9 & 192 & $6.77 \%$ \\
\hline 21 & Immunology & 2 & 33 & $27.27 \%$ \\
\hline 22 & Space Science & 19 & $10.53 \%$ \\
\hline & & & \\
\hline
\end{tabular}

Results in italics indicate that the matching process of the ESI and DOAJ categories was not very sound.

Figures 5 and 6 depict the Quartiles distribution of JCR-indexed OA journal titles. The percentage of Q1 titles is $<20 \%$. The majority of journals are assigned to Q4.

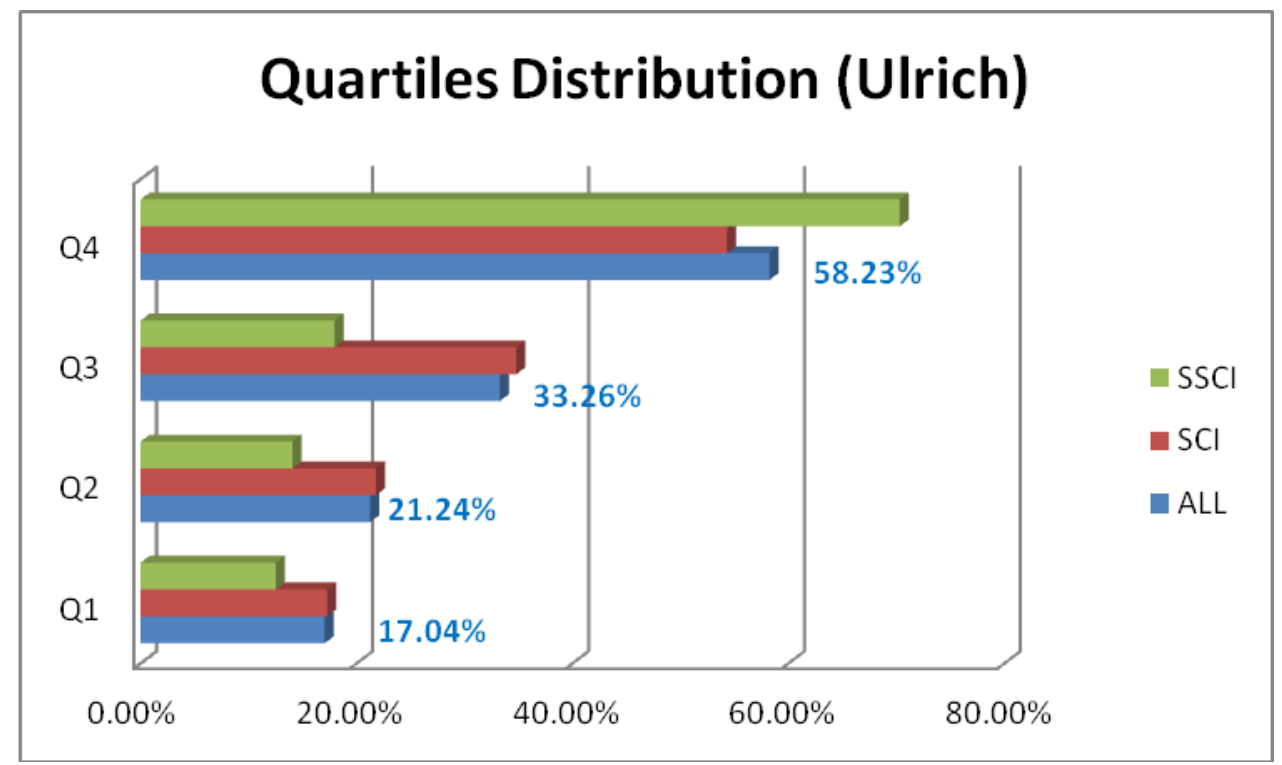


Figure 5: Quartiles distribution of JCR-indexed OA journal titles (according to Ulrich and considering both JCR-Editions (SCI or SSCI))

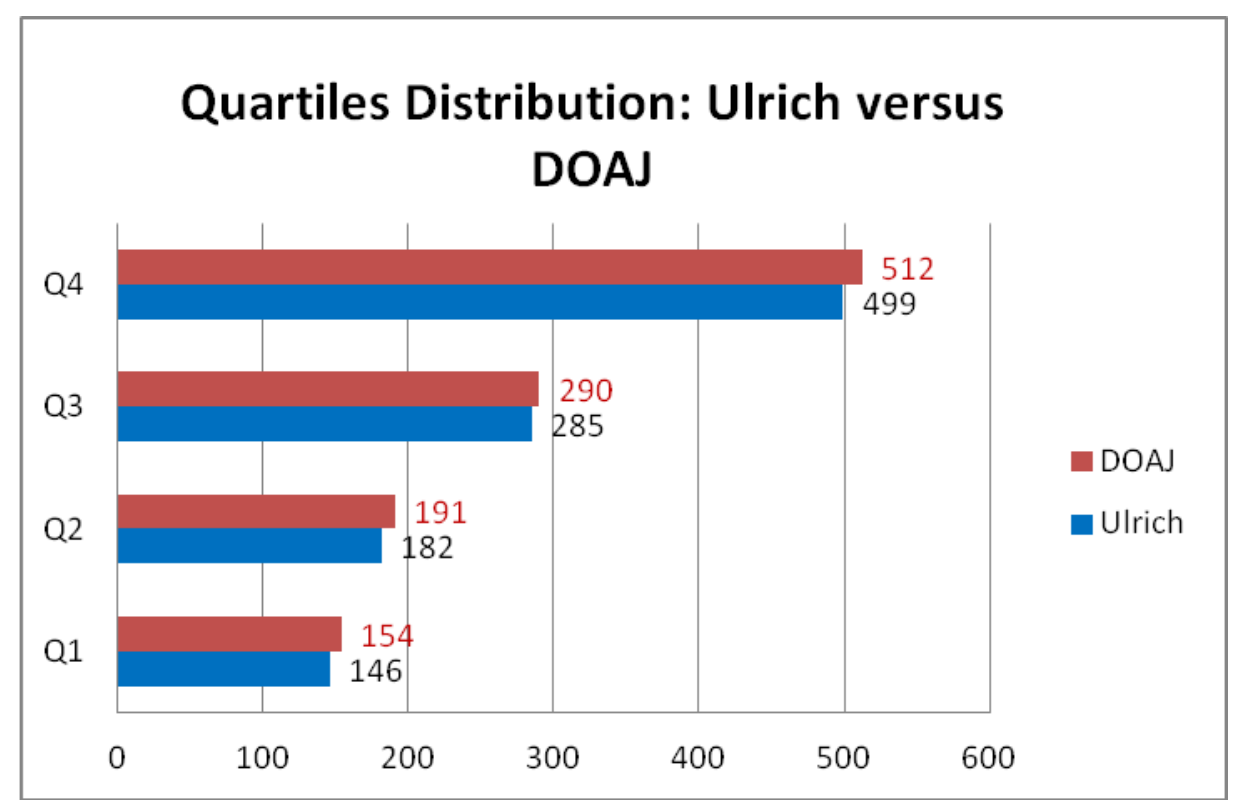

Figure 6: Quartiles distribution of JCR-indexed OA journal titles - Ulrich vs. DOAJ

Table 4 lists all originating countries of Q1 OA journals titles. USA and UK are found on the very top with 41 resp. 31 titles. Germany holds ranking position 3 with 9 titles. The countries presented in italics are the only ones with different values observed in Ulrich and DOAJ.

Table 4: Country distribution Q1 OA titles according to Ulrich and DOAJ

\begin{tabular}{|l|r|r|}
\hline Country & \# Q1 acc. Ulrich & \# Q1 acc. DOAJ \\
\hline United States & 41 & 47 \\
\hline United Kingdom & 31 & 34 \\
\hline Germany & 9 & 9 \\
\hline Switzerland & 4 & 4 \\
\hline Japan & 4 & 4 \\
\hline Canada & 3 & 3 \\
\hline France & 2 & 2 \\
\hline Denmark & 2 & 2 \\
\hline New Zealand & 2 & 2 \\
\hline Finland & 1 & 1 \\
\hline Serbia & 1 & 1 \\
\hline Lithuania & 1 & 1 \\
\hline Netherlands & 1 & 1 \\
\hline Australia & 1 & 0 \\
\hline
\end{tabular}




\begin{tabular}{|l|r|r|} 
Italy & 1 & 1 \\
\hline Norway & 1 & 1 \\
\hline
\end{tabular}

Figure 7 reflects the publisher distribution of Q1 OA journal titles. 28 of the 106 Q1 titles are published by BioMed Central. The same amount of journals is published by 7 publishing houses each represented with at least two titles. The remaining 50 titles originate from 50 individual publishers.

\section{Publisher distribution Q1}

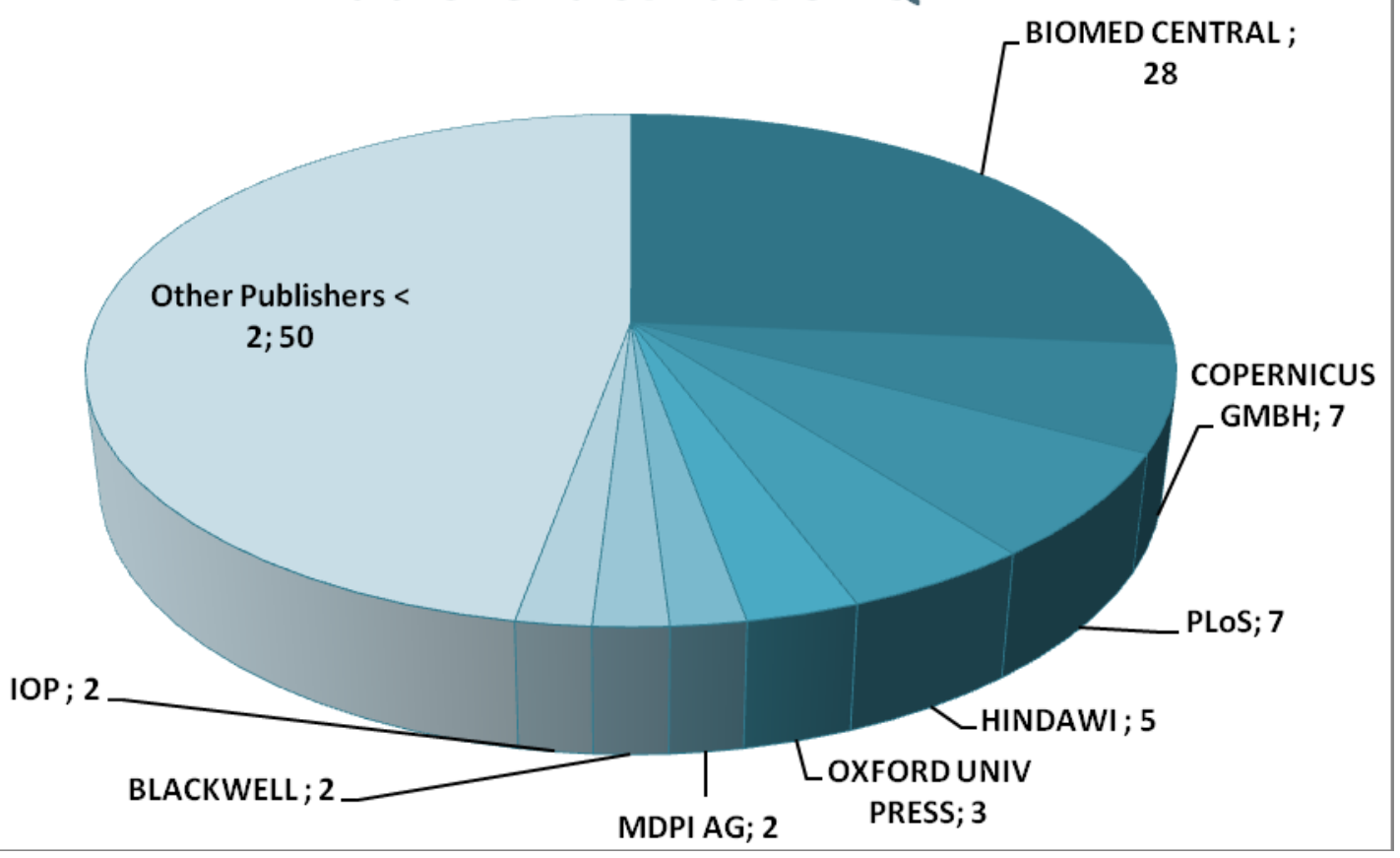

Figure 7: Publisher distribution of Q1 OA titles (according to Ulrich)

\section{4) Analysis of JCR-indexed OA Top-journals}

The top 50 titles according to maximum Impact Factor include the top 40 titles in SCI (5.3\%) and the top 10 titles in SSCI (7.4\%) JCR Editions 2010 (see Table 5).

UK (23 titles) and USA (17 titles) contribute to $80 \%$ of this list. The remaining $20 \%$ originate from Canada (3 titles), Germany and Switzerland (each of them 2 titles, each of them 1 title in the Top 5), and Italy, Spain and Lithuania (each of them 1 title).

All 40 SCI titles belong to Q1, and only 3 out of 10 SSCI titles are assigned to Q2. Only 2 titles are indexed in both SCI and SSCI.

35 titles of the Top 50 list have been OA journals right from the beginning. The remainder was converted at a later point of time. Figure 8 gives an overview of how long it took for the 35 "right from the beginning" OA titles to be included in JCR.

Table 5: Top 50 OA titles according to Impact Factor 


\begin{tabular}{|c|c|c|c|c|c|c|c|c|c|}
\hline Title & $\begin{array}{l}\text { JCR- } \\
\text { Edition }\end{array}$ & $\begin{array}{l}\text { start } \\
\text { year }\end{array}$ & $\begin{array}{c}\text { OA } \\
\text { since }\end{array}$ & $\begin{array}{c}\text { index. in } \\
\text { DOAJ } \\
\text { since }\end{array}$ & $\begin{array}{c}\text { First IF } \\
\text { Year in } \\
\text { JCR } \\
\text { online } \\
\text { eds. }\end{array}$ & $\begin{array}{c}\text { IF } \\
2010\end{array}$ & $\begin{array}{c}\text { Q- } \\
2010\end{array}$ & country & publisher \\
\hline PL o S Medicine & SCI & 2004 & 2004 & 2004 & 2005 & 15.617 & Q1 & USA & PLoS \\
\hline $\begin{array}{l}\text { Living Reviews in } \\
\text { Relativity }\end{array}$ & SCI & 1998 & 1998 & 2003 & 2009 & 12.625 & Q1 & Germany & \begin{tabular}{|l|} 
MPI Gravitational \\
Physics \\
\end{tabular} \\
\hline PL o S Biology & SCI & 2003 & 2003 & 2003 & 2004 & 12.472 & Q1 & USA & PLoS \\
\hline $\begin{array}{l}\text { Molecular Systems } \\
\text { Biology }\end{array}$ & SCI & 2005 & 2005 & 2005 & 2006 & 9.667 & Q1 & UK & $\begin{array}{l}\text { NPG \& Eur. Mol.Biol. } \\
\text { Org. } \\
\end{array}$ \\
\hline $\begin{array}{l}\text { European Cells \& } \\
\text { Materials }\end{array}$ & SCI & 2001 & 2001 & 2004 & 2008 & 9.65 & Q1 & Switzerland & $\begin{array}{l}\text { Eur. Cells \& Materials } \\
\text { Ltd }\end{array}$ \\
\hline PL o S Genetics & SCI & 2005 & 2005 & 2005 & 2006 & 9.543 & Q1 & USA & PLoS \\
\hline PL o S Pathogens & SCI & 2005 & 2005 & 2005 & 2006 & 9.079 & Q1 & USA & PLoS \\
\hline $\begin{array}{l}\text { Nucleic Acids } \\
\text { Research } \\
\end{array}$ & SCI & 1996 & 2005 & 2002 & 1998 & 7.836 & Q1 & UK & Oxford University Press \\
\hline Pain Physician & SCI & 1999 & $?$ & 2008 & 2010 & 7.793 & Q1 & USA & $\begin{array}{l}\text { Amer. Soc. Interv. Pain } \\
\text { Phys. }\end{array}$ \\
\hline $\begin{array}{l}\text { Emerging Infectious } \\
\text { Diseases }\end{array}$ & SCI & 1995 & $?$ & 2003 & 1998 & 6.859 & Q1 & USA & $\begin{array}{l}\text { U.S.N.C. Infectious } \\
\text { Diseases }\end{array}$ \\
\hline Haematologica & SCI & 1920 & $?$ & 2007 & 1998 & 6.532 & Q1 & Italy & Ferrata Storti Foundation \\
\hline $\begin{array}{l}\text { Journal of Lipid } \\
\text { Research }\end{array}$ & SCI & 2002 & $?$ & 2003 & 1998 & 6.115 & Q1 & USA & $\begin{array}{l}\text { Amer.Soc.Biochem. } \\
\text { Mol.Biol. }\end{array}$ \\
\hline $\begin{array}{l}\text { Environmental Health } \\
\text { Perspectives }\end{array}$ & SCI & 1972 & $?$ & 2004 & 1998 & 6.087 & Q1 & USA & NIEHS \\
\hline $\begin{array}{l}\text { Orphanet Journal of } \\
\text { Rare Diseases }\end{array}$ & SCI & 2006 & 2006 & 2006 & 2007 & 5.933 & Q1 & UK & BioMed Central \\
\hline Molecular Medicine & SCI & 1994 & $?$ & 2002 & 1998 & 5.908 & Q1 & USA & Feinstein Ins. Med. Res. \\
\hline $\begin{array}{l}\text { Journal of } \\
\text { Neuroinflammation } \\
\end{array}$ & SCI & 2004 & 2004 & 2004 & 2008 & 5.785 & Q1 & UK & BioMed Central \\
\hline BMC Medicine & SCI & 2003 & 2003 & 2003 & 2008 & 5.75 & Q1 & UK & BioMed Central \\
\hline $\begin{array}{l}\text { PL o S Computational } \\
\text { Biology }\end{array}$ & SCI & 2005 & 2005 & 2005 & 2005 & 5.515 & Q1 & USA & PLoS \\
\hline NeoPlasia & SCI & 1999 & $?$ & 2008 & 2002 & 5.476 & Q1 & USA & Neoplasia \\
\hline $\begin{array}{l}\text { World Health } \\
\text { Organization. Bulletin }\end{array}$ & SCI & 1947 & $?$ & 2004 & 1998 & 5.459 & Q1 & Switzerland & WHO \\
\hline $\begin{array}{l}\text { Molecular } \\
\text { Neurodegeneration }\end{array}$ & SCI & 2006 & 2006 & 2007 & 2009 & 5.361 & Q1 & UK & BioMed Central \\
\hline $\begin{array}{l}\text { Atmospheric } \\
\text { Chemistry and } \\
\text { Physics }\end{array}$ & SCI & 2001 & 2001 & 2003 & 2002 & 5.309 & Q1 & Germany & Copernicus Publications \\
\hline Retrovirology & SCI & 2004 & 2004 & 2004 & 2007 & 5.236 & Q1 & UK & BioMed Central \\
\hline BMC Biology & SCI & 2003 & 2003 & 2003 & 2007 & 5.203 & Q1 & UK & BioMed Central \\
\hline $\begin{array}{l}\text { Int. J. of } \\
\text { Nanomedicine }\end{array}$ & SCI & 2006 & 2006 & 2009 & 2007 & 4.976 & Q1 & UK & Dove Medical Press \\
\hline $\begin{array}{l}\text { Particle and Fibre } \\
\text { Toxicology }\end{array}$ & SCI & 2004 & 2004 & 2004 & 2010 & 4.906 & Q1 & UK & BioMed Central \\
\hline $\begin{array}{l}\text { J. of Psychiatry and } \\
\text { Neuroscience }\end{array}$ & SSCI/SCI & 1998 & $?$ & 2000/1998 & 2001 & 4.893 & Q1 & Canada & Canadian Medical Assoc. \\
\hline DNA Research & SCI & 1994 & 2000 & 2006 & 2002 & 4.754 & Q1 & UK & Oxford University Press \\
\hline $\begin{array}{l}\text { PL o S Neglected } \\
\text { Tropical Diseases }\end{array}$ & SCI & 2007 & 2007 & 2008 & 2008 & 4.752 & Q1 & USA & PLoS \\
\hline $\begin{array}{l}\text { Epigenetics \& } \\
\text { Chromatin }\end{array}$ & SCI & 2008 & 2008 & 2010 & 2010 & 4.731 & Q1 & UK & BioMed Central \\
\hline $\begin{array}{l}\text { Journal of Medical } \\
\text { Internet Research }\end{array}$ & SCI & 1999 & 1999 & 2003 & 2006 & 4.663 & Q1 & Canada & Gunther Eysenbach \\
\hline $\begin{array}{l}\text { Disease Models \& } \\
\text { Mechanisms }\end{array}$ & SCI & 2008 & 2008 & 2011 & 2009 & 4.584 & $\mathrm{Q} 1 / \mathrm{Q} 2$ & UK & Company of Biologists \\
\hline Microbial Cell & SCI & 2002 & 2002 & 2003 & 2007 & 4.544 & Q1 & UK & BioMed Central \\
\hline
\end{tabular}




\begin{tabular}{|c|c|c|c|c|c|c|c|c|c|}
\hline Factories & & & & & & & & & \\
\hline $\begin{array}{l}\text { Annals of Family } \\
\text { Medicine }\end{array}$ & SCI & 2003 & $?$ & 2003 & 2006 & 4.457 & Q1 & USA & HighWire \\
\hline PL o S One & SCI & 2006 & 2006 & 2007 & 2009 & 4.411 & Q1 & USA & PLoS \\
\hline $\begin{array}{l}\text { J. of Cardiovasc. } \\
\text { Magn. Resonance }\end{array}$ & SCI & 1999 & 2008 & 2005 & 1999 & 4.328 & Q1 & UK & BioMed Central \\
\hline BMC Genomics & SCI & 2000 & 2000 & 2003 & 2004 & 4.206 & Q1 & UK & BioMed Central \\
\hline Molecular Pain & SCI & 2005 & 2005 & 2005 & 2007 & 4.148 & Q2 & UK & BioMed Central \\
\hline $\begin{array}{l}\text { Biotechnology for } \\
\text { Biofuels }\end{array}$ & SCI & 2008 & 2008 & 2008 & 2009 & 4.146 & Q1 & UK & BioMed Central \\
\hline Cell Division & SCI & 2006 & 2006 & 2006 & 2010 & 4.091 & Q2 & UK & BioMed Central \\
\hline Ecology and Society & SSCI/SCI & 2004 & 2004 & 2004 & $2011 / 2011$ & 3.31 & Q1/Q2 & Canada & The Resilience Alliance \\
\hline $\begin{array}{l}\text { Computational } \\
\text { Linguistics }\end{array}$ & SSCI & 2000 & 2009 & 2002 & 2000 & 2.971 & Q1 & USA & MIT Press \\
\hline $\begin{array}{l}\text { Implementation } \\
\text { Science }\end{array}$ & SSCI & 2006 & 2006 & 2006 & 2009 & 2.514 & Q1 & UK & BioMed Central \\
\hline $\begin{array}{l}\text { Int. Journal of Health } \\
\text { Geographics }\end{array}$ & SSCI & 2002 & 2002 & 2003 & 2009 & 2.341 & Q1 & UK & BioMed Central \\
\hline $\begin{array}{l}\text { PR Special Topics - } \\
\text { Phys. Edu. Res. }\end{array}$ & SSCI & 2005 & 2005 & 2007 & 2008 & 2.302 & Q1 & USA & APS \\
\hline Inzinerine Ekonomika & SSCI & 2005 & 2005 & 2006 & 2010 & 2.16 & Q1 & Lithuania & Technologija \\
\hline Duke Law Journal & SSCI & 1951 & 1996 & 2003 & 2000 & 2.059 & Q1 & USA & Duke Univ. School Law \\
\hline $\begin{array}{l}\text { Health and Quality of } \\
\text { Life Outcomes }\end{array}$ & SSCI & 2003 & 2003 & 2003 & 2008 & 1.86 & Q2 & UK & BioMed Central \\
\hline $\begin{array}{l}\text { Int. J. of Clin. and } \\
\text { Health Psychology }\end{array}$ & SSCI & 2001 & 2002 & 2005 & 2007 & 1.842 & Q2 & Spain & AEPC \\
\hline $\begin{array}{l}\text { J. of Artif. Soc. and } \\
\text { Social Simulation }\end{array}$ & SSCI & 1998 & 1998 & 2003 & $2003 *$ & 1.733 & Q2 & UK & Univ. Surrey \\
\hline
\end{tabular}

\section{\# Journals according their IF-delay}

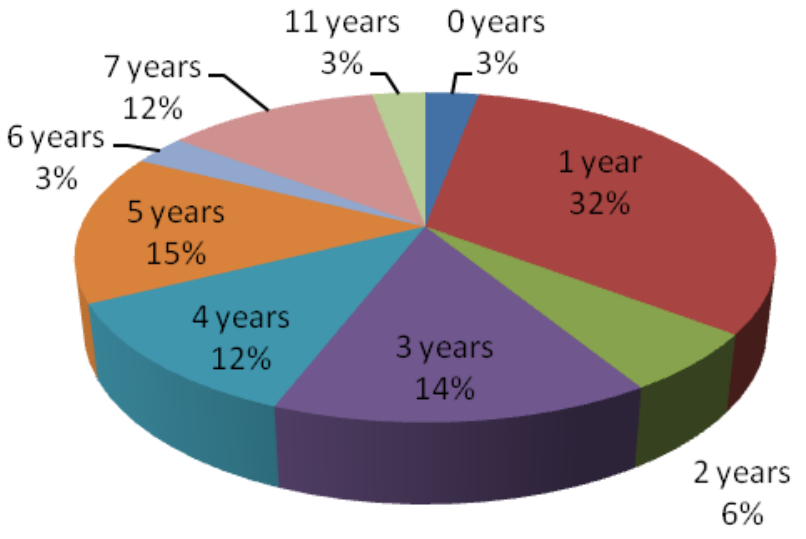

Figure 8: Overview of delay intervals to be indexed in JCR 


\section{5) Temporal evolution of Top $50 \mathrm{OA}$ journals - comparison of journal impact measures}

For the top 50 titles (according to maximum Impact Factor) the temporal evolution of the journal impact measures Journal Impact Factor, SJR and SNIP was analyzed comparatively (see Table 6).

Overall uptrend lines regarding journal impact were found for the majority of the analyzed titles. 20 out of 40 SCI titles showed clear uptrend lines for all 3 journal impact measures, and 14 out of 40 SCI titles at least uptrend lines for 2 of the indicators. Moreover 4 out of 10 SSCI titles were detected with increasing trend lines for either 3 or at least 2 journal impact measures (each group represented with 2 titles).

Downtrend lines were hardly observed (bolded titles in Table 5). 7 SCI and 3 SSCI titles were identified with a negative slope for 1 indicator, and only 2 SCI and 1 SSCI title showed decreasing trend lines for 2 indicators. Discrepancies in the indicator timelines were analyzed for these few titles. For PLoS Biology, Nucleic Acids Research, Emerging Infectious Diseases and Journal of Lipid Research the increase of the number of articles and the decrease of the number of review articles has been found as an explanation; whereas quite the opposite is the case for Molecular Medicine. Uptrend SNIP values for PLoS Biology and BMC Genomics are explicable due to the decreased Raw Impact Factor along with also decreased Database Citation Potential.

Discrepancies observed for a few titles simply originate from the fact that either none or only insufficient data were available for the analysis.

Comparative indicator timelines are exemplarily shown for PLoS Biology in Figure 9.

Table 6: Temporal evolution of the Top 50 OA titles (according to Impact Factor)

\begin{tabular}{|c|l|l|l|l|l|}
\hline$\#$ & \multicolumn{1}{|c|}{ Title } & \multicolumn{1}{|c|}{$\begin{array}{c}\text { JCR- } \\
\text { Edition }\end{array}$} & $\begin{array}{c}\text { Trend } \\
\text { IF }\end{array}$ & $\begin{array}{c}\text { Trend } \\
\text { SJR }\end{array}$ & $\begin{array}{l}\text { Trend } \\
\text { SNIP }\end{array}$ \\
\hline 1 & PLoS Medicine & SCI & $\uparrow$ & $\uparrow$ & $\uparrow$ \\
\hline 2 & Living Reviews in Relativity & SCI & $\uparrow$ & $\leftrightarrow$ & $\uparrow$ \\
\hline 3 & PLoS Biology & SCI & $\downarrow$ & $\downarrow$ & $\uparrow$ \\
\hline 4 & Molecular Systems Biology & SCI & $\uparrow$ & $\uparrow$ & $\uparrow$ \\
\hline 5 & European Cells \& Materials & SCI & $\uparrow$ & $\uparrow$ & $\uparrow$ \\
\hline 6 & PLoS Genetics & SCI & $\leftrightarrow$ & $\uparrow$ & $\uparrow$ \\
\hline 7 & PLoS Pathogens & SCI & $\uparrow$ & $\leftrightarrow$ & $\uparrow$ \\
\hline 8 & Nucleic Acids Research & SCI & $\uparrow$ & $\downarrow$ & $\uparrow$ \\
\hline 9 & Pain Physician & SCI & n.a. & $\uparrow$ & $\uparrow$ \\
\hline 10 & Emerging Infectious Diseases & SCI & $\uparrow$ & $\downarrow$ & $\uparrow$ \\
\hline 11 & Haematologica & SCI & $\uparrow$ & $\uparrow$ & $\uparrow$ \\
\hline 12 & Journal of Lipid Research & SCI & $\uparrow$ & $\downarrow$ & $\uparrow$ \\
\hline 13 & Environmental Health Perspectives & SCI & $\uparrow$ & $\uparrow$ & $\uparrow$ \\
\hline 14 & Orphanet Journal of Rare Diseases & SCI & $\uparrow$ & $\uparrow$ & $\uparrow$ \\
\hline 15 & Molecular Medicine & SCI & $\uparrow$ & $\downarrow$ & $\uparrow$ \\
\hline 16 & Journal of Neuroinflammation & SCI & $\uparrow$ & $\uparrow$ & $\uparrow$ \\
\hline
\end{tabular}




\begin{tabular}{|c|c|c|c|c|c|}
\hline 17 & BMC Medicine & SCI & $\uparrow$ & $\uparrow$ & $\uparrow$ \\
\hline 18 & PLoS Computational Biology & SCI & $\leftrightarrow$ & $\uparrow$ & $\uparrow$ \\
\hline 19 & NeoPlasia & SCI & $\leftrightarrow$ & $\leftrightarrow$ & $\uparrow$ \\
\hline 20 & World Health Organization. Bulletin & SCI & $\uparrow$ & $\uparrow$ & $\uparrow$ \\
\hline 21 & Molecular Neurodegeneration & SCI & $\uparrow$ & $\uparrow$ & $\uparrow$ \\
\hline 22 & Atmospheric Chemistry and Physics & SCI & $\uparrow$ & $\uparrow$ & $\uparrow$ \\
\hline 23 & Retrovirology & SCI & $\uparrow$ & $\uparrow$ & $\uparrow$ \\
\hline 24 & BMC Biology & SCI & $\uparrow$ & $\leftrightarrow$ & $\uparrow$ \\
\hline 25 & Int. J. of Nanomedicine & SCI & $\uparrow$ & $\uparrow$ & $\uparrow$ \\
\hline 26 & Particle and Fibre Toxicology & SCI & n.a. & $\uparrow$ & $\uparrow$ \\
\hline 27 & J. of Psychiatry and Neuroscience & $\mathrm{SSCI}+\mathrm{SCI}$ & $\uparrow$ & $\uparrow$ & $\uparrow$ \\
\hline 28 & DNA Research & SCI & $\downarrow$ & $\downarrow$ & $\leftrightarrow$ \\
\hline 29 & PLoS Neglected Tropical Diseases & SCI & $\uparrow$ & $\uparrow$ & $\uparrow$ \\
\hline 30 & Epigenetics \& Chromatin & SCI & n.a. & n.a. & n.a. \\
\hline 31 & Journal of Medical Internet Research & SCI & $\uparrow$ & $\uparrow$ & $\uparrow$ \\
\hline 32 & Disease Models \& Mechanisms & SCI & $\uparrow$ & $\uparrow$ & $\uparrow$ \\
\hline 33 & Microbial Cell Factories & SCI & $\uparrow$ & $\uparrow$ & $\uparrow$ \\
\hline 34 & Annals of Family Medicine & $\mathrm{SCI}$ & $\leftrightarrow$ & $\uparrow$ & $\uparrow$ \\
\hline 35 & PLoS One & $\mathrm{SCI}$ & $\uparrow$ & $\uparrow$ & $\uparrow$ \\
\hline 36 & J. of Cardiovasc. Magn. Resonance & SCI & $\uparrow$ & $\uparrow$ & $\uparrow$ \\
\hline 37 & BMC Genomics & SCI & $\leftrightarrow$ & $\downarrow$ & $\uparrow$ \\
\hline 38 & Molecular Pain & SCI & $\leftrightarrow$ & $\leftrightarrow$ & $\uparrow$ \\
\hline 39 & Biotechnology for Biofuels & $\mathrm{SCI}$ & $\uparrow$ & $\uparrow$ & $\downarrow$ \\
\hline 40 & Cell Division & SCI & n.a. & $\uparrow$ & $\uparrow$ \\
\hline 1 & Ecology and Society & $\mathrm{SSCI}+\mathrm{SCI}$ & $\uparrow$ & $\uparrow$ & $\uparrow$ \\
\hline 2 & Computational Linguistics & SSCI & $\uparrow$ & $\uparrow$ & $\uparrow$ \\
\hline 3 & Implementation Science & SSCI & $\uparrow$ & $\leftrightarrow$ & $\uparrow$ \\
\hline 4 & Int. Journal of Health Geographics & SSCI & $\downarrow$ & $\leftrightarrow$ & $\uparrow$ \\
\hline 5 & PR Special Topics - Phys. Edu. Res. & SSCI & $\uparrow$ & $\leftrightarrow$ & $\downarrow$ \\
\hline 6 & Inzinerine Ekonomika & SSCI & n.a. & $\uparrow$ & $\uparrow$ \\
\hline 7 & Duke Law Journal & SSCI & $\leftrightarrow$ & $\downarrow$ & $\uparrow$ \\
\hline 8 & Health and Quality of Life Outcomes & SSCI & $\downarrow$ & $\leftrightarrow$ & $\uparrow$ \\
\hline 9 & Int. J. of Clin. and Health Psychology & SSCI & $\downarrow$ & $\leftrightarrow$ & $\downarrow$ \\
\hline 10 & J. of Artif. Soc. and Social Simulation & SSCI & $\uparrow$ & $\leftrightarrow$ & $\uparrow$ \\
\hline
\end{tabular}




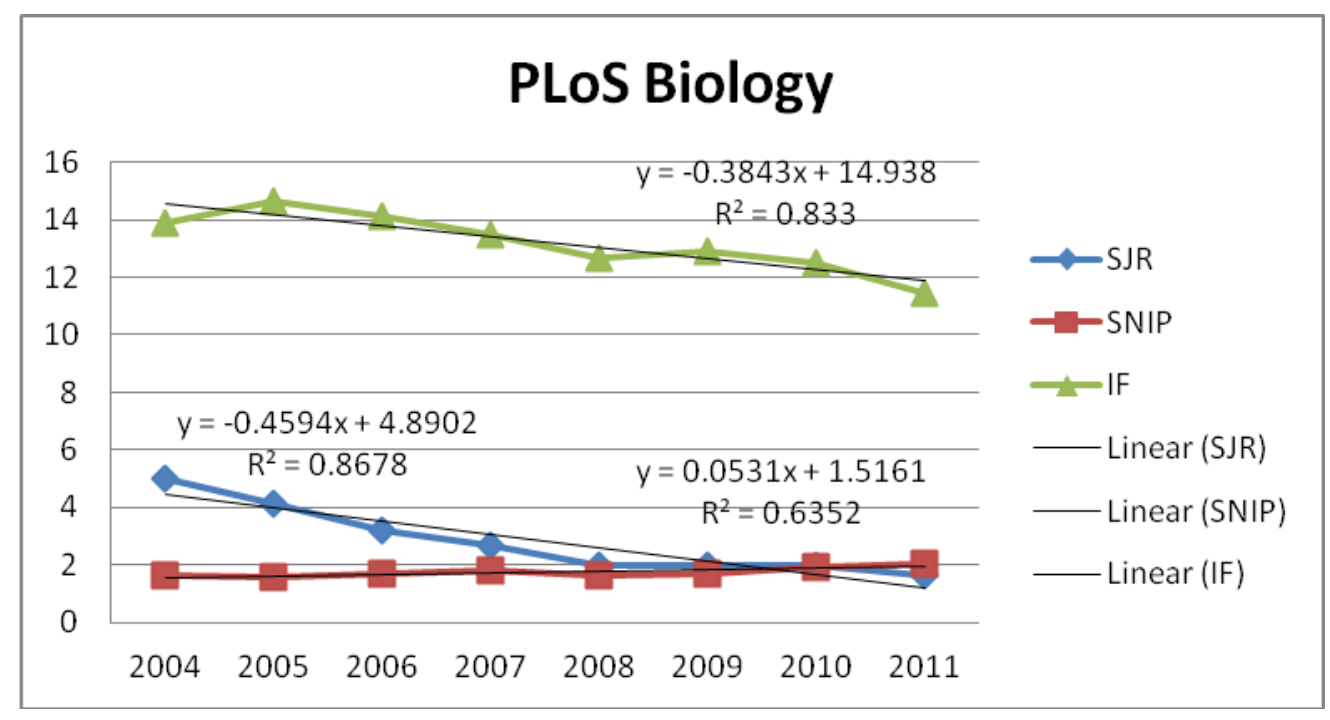

Figure 9: Comparative indicator timelines for PLoS Biology

\section{6) Correlation analysis of journal impact measures}

A Pearson correlation analysis was performed for IF, SJR, SNIP and RIP (= Raw Impact Factor used for the calculation of the SNIP [IF, 3 years, Scopus Data]). The correlation analysis was based on 260 values completely available for all Top 50 titles for all the mentioned indicators in the time interval 2001 - 2011. Looking at SJR and SNIP alone increased the number of available values to 378 , however, the observed correlation coefficients were insignificantly higher.

The results are shown in Table 7. As evident correlation coefficients between IF and RIP as well as between IF and SJR suggest a rather strong correlation, whereas there is no correlation between SJR and SNIP as well as between IF and SNIP due to the different metrics characteristics. In case of SNIP the corrections for journal subject fields and database coverage need to be taken into account as well.

Table 7: Pearson correlation of journal impact measures

\begin{tabular}{|l|r|l|l|l|}
\hline $\begin{array}{l}\text { Pearson } \\
\text { Correlation }\end{array}$ & IF & SJR & SNIP & RIP \\
\hline IF & & 0,744106799 & 0,111380729 & 0,81716659 \\
\hline SJR & 0,7441068 & & $-0,01405948$ & 0,71085879 \\
\hline SNIP & 0,11138073 & $-0,01405948$ & & 0,29689917 \\
\hline RIP & 0,81716659 & 0,71085879 & 0,29689917 & 0,71085879 \\
\hline
\end{tabular}




\section{Discussion and Conclusions}

\section{1) Identification of $\mathrm{OA}$ titles in the used data sources}

Bibliometric analyses heavily rely on the underlying data sources, which certainly all have their strengths as well as limitations.

Ulrichsweb seemed to be a suitable data source for this analysis and has also been used in the study by Sotudeh and Horri (2007). However, when performing our first data compilation in May 2012, we already encountered several problems:

\section{- Cumbersome deduplication}

Restriction to "Serial_type = journal" (from over 650.000 items, thereof about 120.000 journal entries) resulted in a hit list where journal titles were listed several times according to the available format (Print, Online, CD, etc.). Manual deduplication was a time-consuming and cumbersome task.

\section{- OA labelling in Ulrichsweb and JCR}

Ulrichsweb allows to filter all Open Access titles (Key Features = Open Access) in principle. However, in spite of the common understanding that Open Access journals need to be online, Ulrichsweb also assigns this label to print journals or other formats. More disturbing is the fact that sometimes Open Access journals are listed only as print journals, even though they are either as well or exclusively published as online journals. PloS is the best example as one of the most successful Open Access titles. Except for PloS One all other PloS titles were only listed as print journals in Ulrichsweb when this analysis was performed.

On the other hand, JCR provides no information at all whether a journal title is either closed or open access. As Giglia (2010) observed, it is not possible to extract the list automatically. In the study by McVeigh (2004), the author provided the list of JCR-indexed OA journals as an appendix as of June 30, 2004. But of course this list has changed a lot within the last years and will permanently change in the future. Therefore it is desirable to easily compile it "on the fly" on the Thomson Reuters platform.

\section{- Comparison to DOAJ}

After manual deduplication of retrieved OA titles in Ulrichsweb the result list was narrowed down to 7451 titles in May 2012. As in previous studies by McVeigh (2004), Sotudeh and Horri (2007) and Giglia (2010), this figure was compared to DOAJ which reported $7706^{7} \mathrm{OA}$ titles (245 more than Ulrichsweb). The discrepancy is not too big and can be explained by the preceding issues observed in Ulrichsweb. In comparison to DOAJ the character of Ulrichsweb is more volatile delivering different results in different months.

In spite of the fact that DOAJ seems to be a more reliable and complete data source for OA journals, it could majorly be improved by adding more relevant information per title. Particularly the information whether a title is indexed in JCR or not would be highly

\footnotetext{
${ }^{7}$ In early August 2012 this number has risen to $>8000$ titles.
} 
appreciated by the scientific community. Such flagged titles should also be searchable. Furthermore it is desirable to know if DOAJ titles are indexed in other databases and repositories - apart from the original publisher's website - and ideally provide direct links.

\section{2) Allocation of titles to disciplines, countries and quartiles}

\section{- Subject categories}

It is a well known problem in bibliometrics that different data sources rely on different underlying classification systems. DOAJ's subject categories are based on the Library of Congress classification system, whereas the subject categories in JCR reflect the ones used in the Web of Science. Matching of both systems is cumbersome and only possible to some extent. Therefore it is difficult to judge the obtained results in this regard, which should be taken with a pinch of salt. For bibliometric purposes there is a strong demand for OA databases that provide citation metrics and usage metrics on journal level.

The results of this study suggest that $>50 \%$ of the 886 JCR indexed OA journals belong to the fields of Clinical Medicine (250 titles), Animal \& Plant Science (105 titles) and General Social Sciences (102 titles). The remainder is very much focused on the Sciences, which proves that there is still a lack of JCR indexed OA journals in the Social Sciences and the Humanities.

Due to different categorization it is difficult to compare these findings directly to the results obtained by McVeigh (2004) and Giglia (2010). However, Life Sciences and Medicine have been and still are the predominant subject fields .

- Countries analysis

DOAJ provides explicit country statistics and allows to study the chronological development of OA titles per country. Unfortunately it does not inform about how many of the added titles are finally also included in JCR. This study shows that the percentage of these is very low in general. It also reveals that some countries are obviously more successful to get indexed in JCR than others. The success rate is surprisingly low for German speaking countries. It is evident from the results that particularly countries with many OA journals (like Brazil, India or Spain) are not necessarily successful with getting these indexed in JCR, whereas countries with rather low numbers of OA titles (like Japan, Poland or South Korea) do very well in this respect. Japan really has an outstanding position with a success rate of $>40 \%$ JCR indexed OA titles. Further analyses are needed to figure out the reasons for the different national success rates.

Unfortunately the previous studies by McVeigh (2004) and Giglia (2010) analyzed the geographical aspect only per continent. Therefore it is not possible to directly compare the evolution on country level.

- Quartiles 
Assuming all OA titles to form its own category, the observed Q1 percentage of $17 \%$ is somewhat below the expected value of $25 \%$. Without surprise these Q1 titles are predominantly journals in English language, which is in accordance with the general distribution in JCR.

Regarding publishers it is interesting to see that $30 \%$ of Q1 journals are assigned to only 2 publishers- namely BioMed Central and PLoS - obviously raising the hurdles for their competitors.

\section{3) Temporal evolution of OA journals - comparison of journal impact measures}

Overall it can be said that the identified Top Gold Open Access journals are well-established and their impact is generally increasing for all the analyzed indicators. One third of the 35 newly launched OA titles were already indexed in JCR after 1 year, and $80 \%$ of these received an IF at least within a 5 years interval.

Observed discrepancies in the timelines of the used indicators are well-founded in their different nature (SJR as prestige metric vs. IF and SNIP as popularity metrics). They simply measure different aspects and should therefore be applied complementary.

IF and RIP as well as IF and SJR show significant correlation coefficients as expected and prove that neither the use of WoS vs. Scopus data nor the use of 2 years vs. 3 years citation windows lead to considerably different results.

\section{4) General conclusions}

It is true that the number of real Gold Open Access is still small compared to the total number of scholarly journals world-wide, and even smaller if reduced to JCR-indexed titles. Nevertheless the overall positive impact trend for Top Gold Open Access journals should encourage scientists to publish their findings there whenever an appropriate title is available in their research field. As evident Open Access and high impact are not necessarily in opposition to each other. Björk and Solomon (2012) found, that Open Access journals founded within the last decade as traditional subscription-based journals launched during the same period. They also observed that Open Access journals relying on article processing fees are on average more frequently cited than Open Access journals based on other business models.

Like with traditional journals the same recommendation for authors is also true for Open Access journals: to publish less but more meaningfully in titles that are most appropriate for the conducted research. Publishers of less successful OA titles in terms of inclusion in JCR should review their quality criteria and use the highly successful publishers as role models. Moreover existent titles should be improved before new ones are launched. Hopefully the positive development will also foster the gradual conversion of traditional journals into true Gold Open Access journals. 
Last, but not least increased OA publishing activities of authors should be recognized by responsible research managers operating at universities or research institutes. This should be reflected accordingly in institutional policies, incentive systems and sustainable funding models.

\section{Acknowledgements}

The authors wish to thank Steve Reding and Ambros Wernisch for their support with data compilation.

\section{References}

Björk, B.-C., Solomon, D. (2012). Open access versus subscription journals: a comparison of scientific impact. BMC Medicine 10:73. doi:10.1186/1741-7015-10-73

Craig, I. D., Plume, A. M., McVeigh, M. E., Pringle, J., Amin, M. (2007). Do open access articles have greater citation impact? A critical review of the literature. Journal of Informetrics 1(3), 239-248. doi:10.1016/j.joi.2007.04.001

Garfield, E. (1971): The Mystery of the Transposed Journal Lists - Wherein Bradford's Law of Scattering is generalized. According to Garfield's Law of Concentration. Current Contents, 17, 222-223. Reprinted in: Essays of an Information Scientist, 1, 1962-73. Available: http://www.garfield.library.upenn.edu/essays/V1p222y1962-73.pdf. Accessed: October 29, 2012.

Giglia, E. (2010). The impact factor of open access journals: data and trends. ELPUB2010. Publishing in the networked world:Transforming the Nature of Communication. $14^{\text {th }}$ International Conference on Electronic Publishing, 16-18 June 2010, Helsinki, Finland. Edited by: Turid Hedlund and Yasar Tonta. ISBN 978-952-232-086-5. URI: http://hdl.handle.net/10227/599. pp. 17-39.

González-Pereira, B., Guerrero-Bote, V. P., \& Moya-Anegón, F. de. (2010). A new approach to the metric of journals' scientific prestige: The SJR indicator. Journal of Informetrics, 4(3), 379-391 (also available at: http://arxiv.org/ftp/arxiv/papers/0912/0912.4141.pdf).

Guédon, J.-C. (2008). Mixing and matching the green and gold roads to open access - take 2. Serials Review 34(1), 41-51. doi:10.116/j.serrev.2007.12.008.

Harnad, S., Brody, T., Vallieres, F., Carr, L., Hitchcock, S., Gingras, Y., Oppenheim, C., Hajjem, C., \& Hilf, ER (2008) The access/impact problem and the green and gold roads to open access: an update. Serials Reviews, 34(1), 36-40. doi:10.1016/j.serrev.2007.12.005.

Jubb, M., Cook, J., Hulls, D., Jones, D., \& Ware, M. (2011). Costs, risks, and benefits in improving access to journal articles. Learned Publishing, 24(4), 247-260. doi:10.1087/20110402. 
McVeigh, M. E. (2004). Open access journals in the ISI citation databases: analysis of impact factors and citation patterns. A citation study from Thomson Scientific. Available: http://ipscience.thomsonreuters.com/m/pdfs/openaccesscitations2.pdf. Accessed August 21, 2012.

Moed, H.F. (2010a). The source normalized impact per paper is a valid and sophisticated indicator of journal citation impact. Journal of the American Society for Information Science and Technology, 62(1), 211-213.

Moed, H.F. (2010b). Measuring contextual citation impact of scientific journals. Journal of Informetrics, 4(3), 265-277.

Oppenheim, C. (2008). Electronic scholarly publishing and open access. Journal of Information Science, 34(4), 577-590. doi:10.1177/0165551508092268.

SCImago. (2007). SJR — SCImago Journal \& Country Rank. Retrieved May 2011, from http://www.scimagojr.com.

Schmidt, B. (2007). On the "golden" path - alternative business model for Open-Accessprimary publication. Zeitschrift für Bibliothekswesen und Bibliographie, 54(4-5), 177-182.

Sotudeh, H., \& Horri, A. (2007). Tracking open access journals evolution: some considerations in open access data collection validation. Journal of the American Society for Information Science and Technology, 58(11), 1578-1585. doi:10.1002/asi.20639.

Suber, P. (2004). Open Access Overview: Focusing on open access to peer-reviewed research articles and their preprints. Available: http://www.earlham.edu/ peters/fos/overview.htm.

Accessed: April 11, 2012.

Swan, A. (2010). The Open Access citation advantage: Studies and results to date. Available: http://eprints.soton.ac.uk/268516/2/Citation_advantage_paper.pdf. Accessed: August 21, 2012.

Testa, J., McVeigh, M. E. (2004). The Impact of Open Access Journals. A Citation Study from Thomson ISI. Available: http://www.lib.uiowa.edu/scholarly/documents/ISI_impact-oajournals.pdf. Accessed: October 29, 2012.

Wagner, A.B. (2010). Open Access Citation Advantage: An Annotated Bibliography. Issues in Science and Technology Librarianship, DOI: 10.5062/F4Q81B0W. Available: http://www.istl.org/10-winter/article2.html. Accessed: August 21, 2012].

Zitt, M., \& Small, H. (2008). Modifying the journal impact factor by fractional citation weighting: The audience factor. Journal of the American Society for Information Science and Technology, 59, 1856-1860. 